\title{
Decentralization Analysis of Decision Making and Performance of Accounting Control System.
}

\author{
${ }^{1}$ Drs. Sugijanto, M.Ak., ${ }^{2}$ Dr. Priyono \\ ${ }^{1}$ Department Accounting Faculty Of Economics University PGRI Adi Buana Surabaya \\ East Java in Indonesia \\ ${ }^{2}$ Department Management, Faculty Of Economics, University PGRI Adi Buana, Surabaya ,East Java in \\ Indonesia
}

\begin{abstract}
This study sought to analyze the effect of the delegation of authority and responsibility in the decision-making and influence of accounting controls on performance as measured by election staff, planning, supervision, representation, investigation, coordination, negotiation, evaluation and overall performance.

The method of analysis used in this study is a multiple linear regression test while the sample used in this study are structural and non-structural Officials existing environment PGRI Adi Buana University Surabaya in 2013, from the Head of School to the Head of Sub Division.

On the results of hypothesis testing using Individual Parameter Significance (t-test), indicating that the decentralization of decision-making than the most dominant influence on the performance of accounting control system.
\end{abstract}

Keywords: Decentralization of decision-making, accounting and control system performance.

\section{Introduction.}

One type of control is that accounting control is a form of administrative control and behavioral control (Faisal, 2000) [1], accounting control is a control that is usually for mnciptakan conditions that encourage an organization to achieve desired results or predestined.. An issue of how far the organization structure of decision-making in an organization should be delegated to the level of the lower level has a lot of attention in research organizations, among others: Gordon and Narayanan (1984) [2] and found a significant relationship between organizational structure (decentralization) with the use of accounting systems, while Chenhall and Morris (1986); Miah and Mia (1996) [3] which states that there is a relationship between organizational structure and performance accounting controls. The results are not consistent due to differences in respondents used. Gardon and Nayaranan (1984) [2] using a vice president (top management), while Chenhall and Morris (1986); Miah and Mia (1996) [3] using respondents middle and lower managers (middle and lower level). Heller and Yukl (1969) in Oktaviani (2003) [4], delegation is defined as how much the management at a higher level in the management allow lower levels decisions independently. Delegation is assigning responsibility to management at a lower level (subordinate) to take the necessary actions. According to Gordon and Miller (1976) [5], said that with the increasing complexity of administration, duties and responsibilities to be delegated to management levels lower to ease the burden of the decision pegambilan at higher management levels.

Anthony and Govindarajan (1998) [6], confirmed that the structure of the organization has an important role in influencing performance (efficient and effective) at the organizational level and sub-unit levels. Authority is the right to determine the assignment, while responsibility is the obligation to achieve the tasks set.. Marina (2009) in research Pramita (2012) [7] states that decentralization in the form of distribution of authority in the lower management is needed because of the increasing complexity of the administrative conditions, duties and responsibilities in an organization. So with the delegation of authority to ease the burden of higher management.

\section{Performance}

Performance is the ability to achieve the set targets. In using decentralized organization, achievements in business unit performance is expected to affect the overall performance of the organization, assuming the strategy set at the business unit according to the situation and the external and internal conditions that exist in the business unit (Mia and Clarke, 1999) [8].. According to Peter (1996) in research Oktaviani (2003) [9], by measuring, analysis and evaluation of data relating to the performance, organizations can determine alternative strategies to maintain or improve the efficiency and effektifitas an activity while providing objective information to the public the achievement of results.

\section{Decentralization.}

According to Williamson (1975) in Miah and Mia (1996) [3], decentralized decision-making impact on the achievement of overall corporate performance. With the decentralization of decision-making quality is 
higher than centralization because managers understand the condition of the unit is headed. Soobaroyen and Poorundersing (2008) in Desmiyawati (2010) [10], examine how the impact of decentralization on managerial performance with the use of management accounting systems as an intervening variable. While Chenhall and Morris (1986) [11], decentralized decision-making aimed at improving the performance of managers by encouraging managers to develop their potential. In the study Jaryanto (2008) in Herdiansyah (2012) [12] explained that no direct effect of decentralization on managerial performance, in line with the results of the study are explained Miah and Mia (1996 [3]), which explains that decentralization does not necessarily affect performance but needs to be supported by other factors.

\section{Accounting Control System.}

Anthony and Govindarajan (1998) [13], defines Accounting control system is one of the tools in the form of management control systems that provide organizational control mechanisms or facilities may help to control finances. Lucyanda (2001) [14] suggests that the use of accounting control system is useful in evaluating the performance, because it can motivate manerjer business unit in achieving the goals set parent organization..

The use of accounting control system is intended to facilitate the planning and control of organizational activities with the aim of achieving the expected performance (Miah and Mia, 1996 in Oktaviani, 2003) [5]. The use of accounting information by management is expected to help make the resulting decisions to be more precise and relevant. The accounting system is one of the most important corporate control mechanism that can be used to promote, measure and assess the actions of the executive (management and employees) in an organization (Martin, 1994 in Miah and Mia, 1996) [5] Similarly, Cushing and Romey (1994) [15] argued that the failure to use a system of accounting controls necessary will cause no efektf resource management and organizational performance led to a gradual decline. This illustrates that the use of accounting control system causes changes organizational performance by encouraging decision-making and control of financial activities by managers in a better way.

\section{Methods.}

The method of analysis used in this study is a multiple linear regression test (Uma Sekaran, 2006) [16] while the sample used in this study are structural and non-structural Officials existing environment PGRI Adi Buana University Surabaya in 2013, from the Head of School to head of Sub Division. The number of questionnaires were given to respondents as much as 65 questionnaires, 53 questionnaires had been to do the processing, and 2 questionnaires can not be processed due to incomplete charging while 10 did not return the questionnaire. In this study, respondents who used to head the faculty leadership subpart.

\section{Test Validity and Reliability.}

In this research, so that there is no error in the measurement of some items questions, then tested the validity and reliability of the questionnaire items. Measurement validity is done by using internal consistency (internal consistency) by using the Pearson Product Moment Correlation. The results of the correlation between each item questionnaire with a total score showed significant results, the total score is a value derived from the sum of all the scores of questions every variable. If the significance of $<0.05$ and a correlation $>0.4$ then the item is said to be valid questions which means it has construct validity. As in Table 3.1: The test results showed the validity, acquired all question items in each variable showed significant results (significance $<0.05$ and correlation> 0.4).

Table 1

Validity Test Results

\begin{tabular}{cccc}
\hline Nomor QUESTION & Significance & correlation & Conclution \\
\cline { 2 - 4 } Decentralized Decision Making & & & \\
\hline 1 & 0,000 & 0,821 & Valid \\
2 & 0,000 & 0,780 & Valid \\
3 & 0,000 & 0,841 & Valid \\
4 & 0,000 & 0,770 & Valid \\
5 & 0,000 & 0,706 & Valid \\
\hline Accounting Control System & & & \\
\hline 1 & 0,000 & 0,736 & Valid \\
2 & 0,000 & 0,840 & Valid \\
3 & 0,000 & 0,818 & Valid \\
4 & 0,000 & 0,760 & Valid \\
5 & 0,000 & 0,753 & Valid \\
6 & 0,000 & 0,750 & Valid \\
\hline
\end{tabular}




\begin{tabular}{lllll}
\hline Peformance & & & & \\
\hline 1 & 0,000 & 0,693 & Valid \\
2 & 0,000 & 0,826 & Valid \\
3 & 0,000 & 0,781 & Valid \\
4 & 0,000 & 0,660 & Valid \\
5 & 0,000 & 0,763 & Valid \\
6 & 0,000 & 0,683 & Valid \\
& 7 & 0,000 & 0,774 & Valid \\
8 & 0,000 & 0,830 & Valid \\
9 & 0,000 & 0,727 & Valid \\
\hline
\end{tabular}

Reliability measurements conducted to determine the ability of an instrument to demonstrate the stability and consistency in measuring the concept. Measurement reliability coefficient Cronbach can use alpha $(\alpha)$, which indicates how well an item questionnaire was positively related to items other questions and also indicates whether the respondent answered with a stable or consistent item-item questionnaire that was to one construct. If the Cronbach coefficient alpha $(\alpha)$ of 0.7 or more then the instrument is acceptable. For more careful look corrected item-total correlation of 0.3 when at least question items can be used or relied upon in subsequent data processing. Table 3.2: The results of the test item questions in each variable showed a reliable $(\alpha>0.7)$.

Table 2

Reliability Test Results

\begin{tabular}{lcc}
\hline \multicolumn{1}{c}{ Variable } & $\begin{array}{c}\text { cronbach } \\
\text { alpha }(\alpha)\end{array}$ & Conclution \\
\hline Decentralized Decision Making & 0,842 & Reliabel \\
Accounting Control System & 0,866 & Reliabel \\
Performance & 0,902 & Reliabel \\
\hline
\end{tabular}

Interpretation of Output Test Assumptions.

III. Analysis And Discussion.

Test assumptions in the studies were conducted before the test multiple linear regression (Uma Sekaran, 2006 [16]) consisting of: test normality, multicollinearity test, test and test Autocorrelation heterocedastisity. Normality test In a test of normality is said to have asymptotic normal distribution if the significance> 0.05 . From the table one sample Kolmogorov Smirnov Asymptotic significance to note that the decentralization of decision-making variable of $0.268,0.653$ and accounting control variables and performance variables 0.594 , means that all the data has Asymp sig $>0.05$, so it can be said all of the data were normally distributed..

\section{Multicolinearity test.}

In the multicolinearity test conducted to determine the relationship between the independent variables. If among the independent variables are correlated, it will be difficult to determine which independent variables affect the dependent variable. Multicollinearity test results in the table can be seen that the entire coefficient of $1.199 \mathrm{VIF}<10$, so that it can be said regression in this study are free from multicollinearity

\section{Autocorrelation test.}

In this test are used to determine the correlation between members of series of observation data, the autocorrelation causes the $\mathrm{F}$ test and $\mathrm{T}$ test be inaccurate. Test can be used to detect Darwin Watson (DW) from the model summary table. From the table it can be seen Darwin Watson (DW) $=1.971$ (is between 1.55 to 2.46) can be said to regression in this study are free of autocorrelation..

\section{Test heterocedastisity..}

This test is performed to determine whether any deviation model, because different interference variance between one observation to another observation. By using the method of Spearman Rank meregresikan Corrrelation ie independent variables with confounding variables (residual) can be known of the heterocedastisity. In the ANOVA table, the significance of $\mathrm{F}=0.632>0.05$ and $\mathrm{t}=0.717$ and the significance is also $0.341>0.05$, multiple regression can be said in this study free of heterocedastisity. In addition to drawing scatter plot shows pictures that have residual plots / points do not form a random pattern.

\section{Discussion.}


Statistical tests using analysis of variance (F test) showed a correlation and coefficient of determination between the performance simultaneously with all the independent variables (decentralization and accounting controls) are strong as $\mathrm{R}=0.524>0.5$. Simultaneously test results on the performance seen from the significance level $\mathrm{F}=0.000<0.05$, which means that the independent variables affect the performance simultaneously. Contributions influence the pattern of variation in proportion to changes in the value of the performance demonstrated by the R-square $=0.275$, meaning $27.5 \%$ of the change in performance due to the decentralization of decision-making and control of accounting. This proves if decentralized decision-making and control of accounting has increased, the performance will also increase significantly..

In the results of the test of hypothesis (H1) to determine the effect on the performance of decentralized decision-making, using the Test of Individual Parameters Significance (t-test), the significance of decentralization of decision-making for $0.021<0.05$. These results support the hypothesis, although the performance of the organization based on the rules specified in the delegation of management to allow a higher level of management at a lower level to take decisions or actions are needed quickly, accurately and efficiently..

In the hypothesis test results of two (H2) to determine the effect of accounting control system performance, the results of the $t$ test of significance is looking for accounting control system $0.023<0.05$. These results support the study by Miah and Mia (1996).

From the results of the second test this hypothesis, the value of the standardized beta coefficients and decentralized decision-making system of accounting controls 0.315 and 0.310 , indicating that the effect of decentralization of decision making (dominant) than accounting control system performance.

\section{Conclusion.}

From the test results statistically using analysis of variance ( $\mathrm{F}$ test) showed that the pattern of variation of the variable changes decentralized decision-making and accounting control system to explain the disproportionate influence of the change in performance, proving that the decentralization of decision-making and control of accounting has increased, then the performance will be increased also significantly..

The results of hypothesis testing using Individual Parameter Significance (t-test), indicating that the decentralization of decision-making than the most dominant influence on the performance of accounting control system.

The results of this study can not be generalized more widely, for research conducted at the University of Surabaya PGRI Adi Buana. Based on these limitations for future research is suggested to add or use other variables outside companies / organizations that have an influence on managerial performance considering the uncertainty of the environment is often a factor that caused the organization to adjust to the environmental condition of the organization.

\section{References}

[1]. Faisal, 2000, The Effects of Task Characteristics on the Effectiveness of Shape Control Accounting, Behavior and Performance Improvement Personal.

[2]. Gordon and Miller, 1976., A contingency Framework for the Design of Accounting Information Systems, Accounting Organization and Socity, 56-59.

[3]. Chenhall, RH and Morris, 1986, The Impact and Structure, Environment and Interdependence on the Perceived Usefulness of Management Accounting System, The Accouting Review LXi (1), 16-35.

[4]. Oktaviani, Ayu, 2003, Effect of Decentralized Decision-making Managerial Performance Against Office: Accounting Control System as an intervening variable (Empirical Study: Autonomous Region of South Kalimantan.

[5]. Pramita DSU, 2012, Effect of Environmental Uncertainty and Decentralization Of Managerial Performance with Characteristics of Accounting Information Systems Management as anintervening variable (Empirical Study on Industry Hospital in Central Java).

[6]. Anthony, RN and Govindarajan, Management Control Systems, 9th Edition, Richard D.Irwin Inc., 1998. Mia, L. and Clarke, 1999, Market Competition, Use of infromation Management Accounting System, Business Unit Performance, Management Accouting Research, 137-138.

[7]. Miah, NZ and Mia, L, 1996, Desentralization, Accounting Control System and Performance of Government Organization, A New Zaeland empirical Study, Financial Accountability and Management, august.

[8]. Desmiyawati, 2010, Effect of Decentralization, Environmental Uncertainty and ManagementAccounting Systems on Managerial Performance, Pekbis Journal, Vol.2, No.3, 2010: 346-354.

[9]. Herdiansyah, Singgih, 2012, Effect of Characteristics of Information Systems and Management Accounting Managerial Performance Against decentralization with Environmental uncertainty as Moderating Variable.

[10]. Lucyanda, Y, 2001, Relationship between Budget Participation by Manjerial Performance: The Roleof Locus of Control as Moderating Variables and Motivation as a variable Intervaning.

[11]. Cushing, BE and R> B Romney, 1994, Accounting Information Systems, Addison-Wesley Uma Sekaran, 2006, Research Methods For Business (Research Methodology for Business), Four Salemba, Jakarta. 